See discussions, stats, and author profiles for this publication at: https://www.researchgate.net/publication/333825580

\title{
The limits of participatory democracy and the inclusion of social movements
} in local government

Article in Social Movement Studies · June 2019

DOI: 10.1080/14742837.2019.1629277

CITATIONS

5

1 author:

a Valesca Lima

Maynooth University

26 PUBLICATIONS 43 CITATIONS

SEE PROFILE

Some of the authors of this publication are also working on these related projects:

Project Book - Participatory Citizenship and Crisis in Contemporary Brazil View project

Project Governing cities in the era of sharing economies View project
439 


\section{The limits of participatory democracy and the inclusion of social movements in local government}

\section{Valesca Lima}

School of Politics and International Relations, University College Dublin, Maynooth University, Dublin, Ireland

\begin{abstract}
This paper examines the decentralisation of decision-making processes in local government. Empirically, I analyse how Brazilian housing movements are included in participatory processes by examining the ways in which participatory models integrate social movements in spaces of decision-making. I argue that the rules and focus on incremental policy-making limits the participation of social movements. Findings suggests that unequal power structures at local councils, barriers to the participation of citizens, and the lack of transparency of government decisions all prevent social movements from having a more influential voice in decision-making. Although previous studies in Brazil examined the integration of citizens in government institutions, this paper contributes to the literature in two ways: firstly, it provides new evidence on the impact of decentralisation in local government. Secondly, by examining the attitudes of housing council members towards popular political participation, it provides new insights into the limits of decentralisation and participatory governance in contemporary Brazil.
\end{abstract}

\section{ARTICLE HISTORY}

Received 15 December 2017 Accepted 30 April 2019

\section{KEYWORDS}

Social movements; housing; participatory democracy; local government; decentralization

\section{Approaches to participatory democracy}

The inclusion of citizens in institutional channels of citizen participation has generated prolific debates on the effects on social movements of participating in those spaces. In Latin America, in the post-democratisation period, social movements have engaged with the state in a variety of forms. Policy councils, citizen assemblies and participatory budgets are instances of democratic innovation, which can be defined as institutional innovations that have been specifically designed to increase and deepen citizen participation in the political decisionmaking process (Smith, 2009). They are considered a democratic innovation because they are part of a shift from hierarchical, state-led government - via an official regulatory framework to decentralised, society-led governance by ordinary citizens, including social movements, NGOs, and also individuals and private companies. These innovations are representative of the interest in finding new ways of engaging citizens in the political decision-making process (Polletta, 2013).

The concept of citizenship linking participation rights with governance sustains social movements' claim to influence participatory arrangements. This perspective is 
focused on extending citizenship to ordinary citizens through governance structures, which was a key objective of the Workers' Party (PT - Partido dos Trabalhadores) governments in Brazil. In this way, participatory democracy proposes that citizen participation is essential for the political process, contrary to the neo-liberal notion of democracy, which assumes citizen participation has a marginal and limited role, consistent with the belief that elites are not committed to encouraging political participation (Cohen, 1999; Fishkin, 2009). Participation is how the public is given a voice in policy-making. Hence, if some sectors of society, some demographic groups, or some widely shared viewpoints, are left out, then that voice is distorted (Fishkin, 2009, p. 76).

A critical issue that has emerged regarding the participation of the poor in decisionmaking processes, especially those living in slum-areas, was the way these movements engaged with the state. While theorized as being a potential means for involving the poor in decision-making processes, as well as holding states accountable (Avritzer, 2009), various studies found that, in cases where movements are not successful in developing a meaningful interaction with the state, they tend to have poor gains when it comes to long-term constructive impacts and improvements in the lives of the participants and the wider community (Rodgers, Beall, \& Kanbur, 2012).

In Brazil, elites tend to have a considerable influence on politics (Nylen, 2011). Elites consist not only financial elites (speculation), industrialists, and agribusiness, but also the political class, which want to continue their dominance and influence in politics. This is a significant position, because the upper class and part of the middle class plays an important role in securing the ideological hegemony of the Brazilian elites through schools, universities, churches, and the media, and many civil servants are professionals from these classes (Boito and Berringer, 2014; Boito \& Saad-Filho, 2016). Thus, it is not a surprise that the promotion of participatory rights and equality in Brazil is seen by the upper and middle classes as the same as an unscrupulous attack on their privileges, interpreting the very demand for equality with tantamount suspicion (Souza, 2017). The Workers' Party neo-developmentalist policies challenged Brazilian elites in accepting the extension of social rights and the improvements of living conditions of the poor. Those were benefits they could not enjoy, and a direct affront to their long-lasting privileges, as they saw the political inclusion and benefits for the dispossessed as a threat.

My aim in the present study is to discuss the limits of the integration of housing movements in participatory governance in Brazil. Thus, pondering the role of the state in encouraging participation and the social actors involved in this process, I ask: how does this inclusion play out? Have social movements for housing been properly included at local level policymaking? Based on evidence from qualitative research, this paper argues that civil society and social movements' struggles with the state for power and influence remains one of the central challenges for the full inclusion of social movements in subnational government and to the development of a deep democracy. The goal of this paper is twofold: firstly, I argue that the incorporation of social movements for housing in spaces of participatory democracy, such as municipal housing councils, has a limited effect on the decentralisation of public policy-making; and secondly, in reflecting on the government-controlled implementation of participatory democracy at the local level, I argue that a more nuanced approach is needed in understanding the role of local elites in capturing the state. 
The paper is structured as follows. The next section provides a brief exploration of the mechanisms through which housing movements joined spaces of participatory governance in Brazil, drawing predominantly on urban movements literature. I then present an overview of the research methods, including the case justification. Subsequently, I move on to explore the limitations of participation of housing movements representatives, summarizing the challenges of being heard as citizens representatives in a housing council. These limitations highlight the importance of providing access to relevant information. This is followed by an examination of how a few individuals can have a disproportionate effect in the process of decision-making and how power sharing is not happening to the same degree as expected. The article concludes with some thoughts on the integration of social movements in local government and on the challenges of implementing democratic innovations in periods of political crisis.

\section{State engagement, decentralisation and mobilisation for housing in Brazil}

For various practitioners and academics around the world, Brazil's experiences with participatory democracy became a fruitful area for studies on democratic innovation, and an inspiration for democratic politics and citizen participation in public policy (Abers, 2000; Baiocchi, Braathen, \& Teixeira, 2013; Dagnino, 2007; Dagnino, Olvera, \& Panfichi, 2006; Earle, 2009; Fung \& Wright, 2003). As urban social movements gained visibility and a central role as actors who push for social change in spaces of citizen participation, these movements undergo considerable changes, with their identities being transformed, and other dimensions of social thought and action arising from the institutional discourse being incorporated. The pursuit of institutionalizing practices, that were previously autonomous, become a constant. A regulatory framework has made it possible to generate countless innovations in the field of democratic innovation. From these state practices, a contradictory scenario has appeared, one in which entities might seek mere integration of the excluded (as in Arnstein's (1969) ladder of participation). This integration could happen through participation in exclusively compensatory social policies, existing side by side with movements, networks and social forums that seek social transformation through changes in the development model that predominates in Latin America and Brazil (Baiocchi \& Ganuza, 2016; Gohn, 2015).

The decentralization of the Brazilian state, codified in the 1988 Constitution, unlocked institutional spaces for non-state actors to carry out innovative reforms. The new Constitution introduced a wide variety of participatory mechanisms, including management councils in different areas (education, health, housing, and social security) and new responsibilities for local governments. The social movements increased political autonomy, greater discretion for local governments with regard to the allocation of resources and the increasing number of leftist political actors previously engaged in protests to end the military regime and now willing to contest elections, turned their attention to better opportunities for democratic innovation (Baiocchi, 2003; Heller, 2012). However, it does not mean that the political elites watched those changes impassively. Decentralisation theory highlights the role of the Brazilian elites on the implementation and success of participatory innovations in the region. Brazil has a variety of strong regional elites, which have been able to keep a stranglehold on power even after the wave of decentralisation in the 1970s (Baiocchi, Heller, \& Silva, 
2011). The upper-classes play a crucial role in preventing social reforms, as they were also integrated in some structures of local government.

Political decentralization offered more autonomy to Brazilian municipalities, which are relatively free to allocate resources according to population needs, as long as it complies with fiscal and accountability laws. In the housing area, the responsibility for implementing housing policies lies at the local level and, only in some cases (i.e. large housing projects), in partnership with the federal government. For this reason, municipal housing councils have an important role in defining housing policies locally. The transfer of resources from federal to subnational governments is conditional on the creation of participation forums at the federal, state and municipal levels of public administration. Thus, for a municipality to be entitled to financial resources from federal funds, it is necessary to create councils organized in accordance with legal determinations - federal, state and municipal regulations - as well as administrative procedures. The council is responsible for not only creating local housing plans and determining mechanisms to establish rules for the composition of the council; it is also responsible for implementing power-sharing mechanisms, improving the political representation of diverse groups of citizens and enhancing the transparency and accountability of municipal governments.

The challenge for housing movements engaged in participatory policies has been precisely how to convert this democratic innovation into meaningful state policies that promote citizenship, rather than re-clientisation or co-optation (Baiocchi, 2003). Prior studies have reported mixed findings around the positive and negative results of the inclusion of social movements in public spaces in Brazil (Dagnino \& Teixeira, 2014; Bronstein, Filho, Rubens, \& Pimenta, 2017; Carlos, Silva, \& Almeida, 2018; Dagnino, 2007). However, if the implementation of experiences of participatory democracy is linked to the creation of an authentic participative public space in Brazil or is simply a device to be integrated in contexts that are not open participatory democracy, as I intend to develop in this paper, then further exploration of the complexities of these processes of inclusion is important for theories of participatory democracy and citizen participation beyond Brazil and Latin America.

In previous studies, housing movements have been analysed by measuring whether their participation in housing councils are successful and whether their participation generates more social housing units (Touchton \& Wampler, 2014; Donaghy, 2011, 2013). Those studies found that, since the introduction of participatory experiences in housing policies, there are more housing projects and there is more investment in housing in general. There is greater availability of funding, security of tenure, urbanisation of informal settlements, title possession, etc., and it is clear this 'success' in social housing policy is connected to the existence of a council (Touchton, Wampler, \& Borges Sugiyama, 2016; Wampler, 2007; Wampler \& Touchton, 2014). Donaghy (2011) found in particular that municipalities that have an active housing council tend to implement a wider variety of social housing programs, and that participatory democracy has a positive impact on policy outcomes. Based on these previous academic work, I assume that there is enough evidence to believe that participatory democracy has a positive effect on the outcomes of public policy. However, it is necessary to recognise that other experiences were far less successful (Goldfrank \& Wampler, 2008; Wampler, 2008). In the case under examination in this article, members of the council expected the council to work well there, under PT- 
administered coalitions, but it became more a place for consultation and placation, a similar result also seen in the seminal work of Arnstein (1969), as council representatives were disinterest in sharing political decision power.

\section{Methods and case study}

The housing deficit is a serious concern in Brazil, particularly in the North-East of the country, the region with the highest concentration of poverty and the one least developed. The municipal housing council in the city of Maracanau, in the state of Ceará, in the North-East of Brazil was selected with the objective of achieving the greatest possible amount of rich information. This case study emphasizes the rich, real-world context in which the phenomenon of political participation in municipal councils occur.

Maracanau is a satellite city, economically connected with the capital, Fortaleza. In the last census in 2010, the city population was 200,000, which according to IBGE (2015), is the size of an average size municipality in Brazil. Other characteristics of note include: Maracanau was one of the Brazilian municipalities that created local councils after the new legislation implemented by PT that made it mandatory for all municipalities to open management councils (during Lula's first term in office). In this sense, the city follows the same path as thousands of other cities, in terms of adapting to new legislation. Although a vast academic literature on participatory institutions has been published to date about Brazil, it focuses overwhelmingly upon large cities, and many commit the error of presuming that what happens in São Paulo or Rio de Janeiro is 'representative' of Brazil (Garmany, 2011). For this reason, this case study of a middlesized city in the North-East is a rich case that offers an empirical description of a particular phenomenon.

The municipal housing council in Maracanau was created in 2007 after the mayor, who was part of a party coalition composed of the Liberal Party, the Workers' Party, and a broad-based of centre-right parties, was elected in October 2012. The mayor himself was a member of the Liberal Party (centre-right) and his coalition won the majority of the municipal councillors' seats. The municipality never had a mayor from the Workers' Party. ${ }^{1}$ This coalition, however, was purely electoral and did not represent the political agenda of the politicians in office at the time of fieldwork (2014/15).

My case selection is informed by a strategic selection of cases, which allows me to empirically investigate a contemporary phenomenon in depth, and within its real-world context, especially when the boundaries between phenomenon and context may not be clearly evident (Yin, 2003). In this study, I used a variety of data sources, such as semistructured interviews, demographic survey questionnaires, meeting minutes, official documents and local newspaper articles. From this material, I obtained rich, empirical descriptions of the specific phenomenon under investigation. Thus, this research focuses on this particular municipal housing council in Brazil, as it presents a unique opportunity to examine and investigate the integration of social movements in the policy-making area at the local level, in an in-depth, multi-faceted way.

In the present study, I focus on qualitative forms of inquiry, namely semi-structured in-depth interviews, in order to elicit detailed individual and in-depth narratives of time and place (Yin, 2003). Out of the 29 people interviewed for this study, 22 were members of the municipal housing council in Maracanau. Of those 22 members, 15 are 
representatives of SMOs (Social Movement Organisations, both members and former members of the council) and seven are public officials. Among the SMO representatives, four are former representatives of the housing council and 11 were current representatives. Among the public officials, five were current representatives and two are former representatives. In addition, seven interviews were conducted with activists from SMOs without membership in the housing council in the same municipality and one activist was part of the housing council in the past. These participants have been participating in social mobilisation for housing in the municipality for a considerable time and thus they provide interesting insights from their perspective.

Up to now, this paper has focused on defining the context of this research and the nature of the case study. I now move to examine the limits of participation in the housing council.

\section{Social movements and their relationship with institutional channels of participation}

The housing movement in Brazil is quite diverse, composed of a set of organizations linked to policies, organisations, domains and repertoires, and its origins are possibly connected to the processes of urbanization, industrialization and exploitation of the working class (Kowarick, 2009; Tatagiba \& Teixeira, 2016). Within this diverse group, we find several types of housing movements, organised at the national and local level, which despite their particularities, are guided by the enforceability of the right to housing. They adopt similar political strategies, using diverse repertoires of political action, including participation in institutionalized spheres, such as housing councils, and in collective actions, such as social mobilisation and protest.

At the local level, many of the organisations are informal. They have access to few resources and use their capacity to mobilize the population as a basis for reaching their goals. Their approach to the state is elusive, since it may reverse some co-optation of its leaderships as a result of government and partisan interests. Even though the institutional architecture of participation', elaborated during the Workers' Party administration in 2005 (Dagnino and Teixeira, 2014), presupposes the effective participation of social movements and other civil society organizations through public policy councils, this participation model is state-led, so it is the government who defines conditions of participation.

For SMO council members interviewed for this study, the role of government should be to share information with council members on the technicalities of housing projects and programs they do not understand or do not have knowledge of, so they can make informed decisions. However, findings suggested that the process of sharing information is centralised and selective. For example, government officials keep information and important decisions away from SMO council members, as illustrated by interviews that alluded to the lack of transparency in the housing council. Another problem reported by nearly $70 \%$ of those who were interviewed indicated that public officials often overmanage how the council meeting develops and the outcomes of it, as they exploit SMOs' limited knowledge on policy matters and their little time to prepare for meetings. This claim was evidenced by the mode in which council meetings are conducted.

The issue of over-management was first identified in interviews and later substantiated supporting documents. Analysis showed that municipal officials are frequently 
inclined to use the municipal council as a consultative body. They come to meetings prepared with well-structured proposals and by moving quickly from one topic to the other, they manage to approve their proposals without much consideration from council members. This practice discourages further debates. When it is a SMO member making a proposal, municipal officials often disqualify their ideas, arguing that they are irrelevant or that 'they understood things erroneously.' ${ }^{2}$ One SMO member representing the Association of People with Disabilities suggested that often public officials discourage active participation in the council. Commenting on that, this interviewee said: '(...) the government has the role of decentralising, but they centralise information, and their role is to explain to us how difficult it is to turn them (SMO proposals) into reality' (P-4). ${ }^{3}$ This view was echoed by other informants, which potentially indicates that public officials try to filter which information is released to council members. For the interviewees, it is rather a disappointing result. Membership on the housing council increase the likelihood social movement representatives have a guaranteed say or influence on the outcomes of public policies. While this can happen, council membership does not necessarily ensure that this is the case.

Turning now to the way SMO council members participate during council meetings, there were suggestions that public officials and SMOs representative do not have the same speaking time during the meetings. This is evident in the case of this SMO female participant. The comment below illustrates an episode when a social worker shushed her during a meeting: 'I raised my hand twice, twice I did it and she ignored me the whole time ... ! I started to talk and the man next to her made a shush sign to me. I did not like that.' (P-2). ${ }^{4}$ This passage is an example of the attitude of some municipal agents towards SMO representatives: a possible attempt to avoid political debate that might put government proposals in danger of not being approved. In this excerpt, it is important to consider that the case study fits within a model of affirmative democracy, which combines a dependent civil society with an institutionalized demand-making structure (Baiocchi et al., 2011) and that as much as social movements representatives are frustrated with the process, they are part of an institutionalized demand-making structure (Hodgson, 2004).

A recurrent theme in the interviews with civil servants was a sense amongst them that council members from SMOs often make their arguments in a manner that does not seem structured, usually centred on very local issues in their communities. As a consequence, their discourse sounds too emotional to some officials. Essentially, this style of intervention in the council meeting is associated with poor and/or uneducated people.

An important point to be underlined is the profile of the participants in the councils. It is possible to observe a certain level of homogenisation of participants. From interview profiles, I collected the information that those representing government institutions (in the areas of health, education, transport, for example) are more educated and have higher average incomes as members of the civil service. This is evidenced by the fact that the majority of SMOs members of the housing council have less access to education, especially tertiary education, which creates a clear pattern between SMO representatives and public officials (out of the 22 SMO representatives, only three had an academic degree). During the interviews, most of the council members revealed they had trouble with terminology, jargon and technical language used in the housing council. Prior studies have also noted how language can be an obstacle for participation. 
Wendhausen and Caponi (2002), also found in that in a local health council in the state of Santa Catarina, Brazil, the technical language on health is used as an obstacle to the dialogue between members of the council and local government.

What stands out from the profile of members of the housing council is the somewhat counterintuitive 'division' among council members - on one side, low-income members, with medium-to-low schooling and lacking knowledge in public policy legislation; on the other side, public officials with third-level degrees, medium-to-high income and specialised in public policies. The municipal council is officially a space to deepen citizen participation in the political decision-making process, through the decentralisation of power. But inequality is present in the housing council in the form of access to information and knowledge of public policy.

The meeting minutes on the whole demonstrated that government representatives only partially share information and only when under pressure, as public officials want to ensure their influence over what gets approved in the housing council by avoiding debates that can lead the discussion in a different direction. For example, one meeting minutes read: 'council member (name) tried to explain the project to council members but was interrupted with questions from the plenary' or 'the plenary insisted in inserting new items onto the agenda of the day and the president authorised it'. This attitude reinforces the impression that council members need to pressure public officials to include their demands as a priority in the government's agenda.

Another part of the interview was concerned with strategies to prevent SMO council members from becoming challengers. When asked about the limits of participation in the council, participants were unanimous in the view that in order to make the council manageable for government officials, it is common that someone with no experience in housing policies or no interest in housing issues is appointed to represent the government in the council. The head of the secretariat, which has full discretion on this choice, appoints government representatives in local councils. It could work as an approach to guarantee that particular appointees will be, in some way, manageable or at least will not offer any form of opposition to government proposals. The following illustrates an account of events surrounding a situation when two civil servants, who were usually engaged with local communities and used to criticise government decisions, were not appointed to any local councils anymore. Instead, the government appointed two other people with no experience in housing policies and 'Rachel and Patricia, ${ }^{6}$ who are much more politically-articulate girls, were left out. Then, they put two people who were parachuted in, who were transferred from the local hospital to the housing sector' (P-19). ${ }^{7}$ This public official is criticising the government for appointing to the council someone with no experience in housing issues.

These results suggest that divisions in the housing council highlight important differences among council members - see, for example, Donaghy (2013). Access to formal education and knowledge on housing policies creates a layer of resistance between government officials and SMO representatives. The challenge of keeping the government accountable, transparent and open to popular demands remains the predominant task for SMOs on the housing council. Public officials' strategies to avoid active council members include holding information from members and discouraging debates on government proposals, and it reflects the lack of political willingness to share decision-making power. 
Together these results provide important insights into the sharp differences between the representation of those on the government bench and that of the representatives of social movements, since the former are, in general, specialized authorities qualified to work out technical information for the elaboration and implementation of a policy and have greater access to the information. On the other hand, the representatives of social movements are integrated in the housing council for their capacity to mobilize and for the legitimacy with their supporters' base, and not necessarily for their technical knowledge. Moreover, the state itself is the producer of much of the information discussed in the council, so it would not be an exaggeration to expect that, in some circumstances, the information could be released prior to council meetings. In the next section, I examine the relationship between citizen participation and the power of the elites.

\section{Citizen participation and elite power}

Participatory democracy maintains the strong narrative that 'participation' makes institutions more transparent and accountable to the citizens. This participation should work as a check on elite influence, keeping active citizenship in local governance alive, while incorporating the voices of citizens in the representative democratic system. Citizen participation, however, cannot provide this check on elite power, because these participatory mechanisms are not designed to do so. By addressing the issue of inclusion, it is essential to acknowledge that this is not just an end result of an institutional design that restricts the influence of social movement representatives in the decision-making process. There are also exogenous dynamics that affect the proper inclusion of social movements in spaces of decision-making. I will, therefore, consider a specific dynamic among social movement representatives in the housing council - a dynamic, I argue, that further highlights the limits of citizen participation and power-sharing.

In the municipal housing council, I am studying, SMO representatives face resistance to their full inclusion in the process of decision-making, despite the fact that they are members of the housing council, in the face of the prominent role of the private sector in social housing developments. It means that the decentralisation of public policy decision-making might not be promoting the variety of voices and interests in this scenario, but possibly reproducing the entrenched power of local elites. Even if the aim of council members is to make government decisions more accountable and transparent, there is no contesting of the elite character and influence in decision-making. While it would be naive to assume that all decisions within the housing council were reached by consensus, after a well-informed debate, it became evident that SMOs are able to challenge powerful local groups. Where democratic participation seeks to increase citizens' influence in decision-making and change power-relation dynamics, the consensus is not necessarily reached by agreement and collaboration between the parties involved, but rather by imposition due to the lack of information and social bias (Fishkin \& Luskin, 2005).

Despite the role of the state in shifting from that of governing only through direct forms of hierarchical control to that of shared decision-making power - where the government is assumed to work collaboratively with a broad range of social actors this power-sharing is not actually happening as it would be expected by SMO members. The outcomes of participation are, so far, twofold. Firstly, on the part of social 
movements, they are unable to promote changes in policy without access to significant and timely information on issues that concern public housing and are also not capable of contesting this participatory model. As it is, there is little that they can do in these spaces. Secondly, regarding the institution, I observed that good representation is necessary, since it is not uncommon for certain governments to send to councils' officials unprepared or little motivated, just to comply with the law which, in practice, makes negotiation and consensus unfeasible.

As is often the case in Latin America, those outcomes may be due to state capture by Latin America's wealthy and powerful elites, who historically have been able to tilt government interventions in their favour more often than not (Cannon, 2016; LópezCalva \& Lustig, 2010; Touchton et al., 2016). The decisive shift to the left in Latin America, including Brazil, known as the 'Pink Tide', challenged the deep-rooted power of the elite in many ways (Baiocchi et al., 2011; Cannon, 2016). The threat that power decentralisation has posed to elite social power has motivated them to mobilize their significant resources and influence in order to neutralise grassroots organisations that threaten their dominance. The capturing of the state by local elites allows them to attain power over pro-poor policies, using state officials as their voice in the housing council and imposing their agenda against the interests of SMO representatives. As appointed by Wampler (2008), council participants are in direct competition over the distribution of scarce resources. A successful implementation of participatory democracy would reduce the informal and formal powers of public officials and local elites, which is why those groups may be hostile to this new institutional space.

Wampler (2008) found in his study about participatory budgeting that participatory democracy is, when implemented without the strong support of civil society, social movements and public officials, unlikely to present positive outcomes as those in Porto Alegre. He argues that, when the basic support from the government and the delegation of authority is low, it is not likely that programs such as participatory budgeting will make any significant contribution to the deepening of democracy (p. 281). Despite the fact that the housing council incorporates social movements, support for the delegation of authority is low, and thus the processes of the council are still chiefly led by government with little input from citizens.

My findings corroborate Wampler's research results. Yet, I did not find the same results in terms of party coalition. Even though the same party coalition has ruled over the process since 2003, there is no association between the delegation of power and a coalition committed to participatory democracy. Wampler argues that when the same political coalition has governed the participatory budgeting programs from inception, it is possible to observe more delegation of authority and more negotiation. My research results indicate that SMO members of the housing council are unable to exert authority on decisions regarding social housing because the design of the council does not allow them to do so, as observed by civil servant's resistance in letting SMO members to exercise their agency.

Another significant aspect of this process of participation at the local level is the inequality among council members and the amount of information they have access to. This is potentially the 'most serious weakness' in the participatory democracy model (Fung \& Wright, 2003, p. 33). These inequalities are a consequence of socioeconomic differences and the class background of council members, the knowledge 
that separates experts and technicians from unskilled council members, and are also the result of personal capacities for deliberation and persuasion. Thus, a space of deliberation might become a space of domination: the more those in advantaged backgrounds participate in those spaces, the more likely they will use the tools at their disposal (knowledge, skills, information, authority) in order to advance decisions in favour of government and private sector interests (Fung \& Wright, 2003; Lima, 2018; Cornwall, 2008).

While it is a fact that spaces of participation can also be spaces of resistance but may actually reproduce inequalities, research in the area of participatory innovation has not yet concluded the debate on which class interests are mobilised and served in policy councils. As seen in Baiocchi (2003), conservative administrations are able, in some cases, to maintain open and participatory forms of popular participation, such as in participatory budgets, while at the same time using influence and privileges to increase opportunities for the influencing of public policies by local elites. Wampler (2008) found that successful participatory budgets enforce a check on clientelist relations and dishonest uses of public resources. However, this does not necessarily curb the ability of resourceful local elites to use their power and influence over the state to limit the redistribution wealth upwards through democratic institutions.

The result of this process of including social movements in local government structures of decision-making reveals the low level of state infrastructure for promoting deep democratisation through participatory democracy. While SMO representatives are required to adapt to state structures, the same has not happened to the state, which changed its internal process to a minimum but did not lose hold of decision-power. Despite changes in legislation that makes decentralisation part of the official discourse (by making the participation of SMO representatives mandatory in local councils, for example) elites have formulated and implemented parameters for citizen participation without the widespread engagement of citizens.

In presenting the differences among housing council members, I argue that the differences among those involved in the housing council and the governance avoidance of the sharing of power are factors of exclusion when it comes to the ongoing integration of SMO representatives in spaces of decision-making, such as the housing council. This exclusion supports the view that unequal relationships are at place among council members, regarding their class background and knowledge on policy-making. This is perhaps one fundamental challenge of participatory democracy - to promote a level playing field for all those participating in the political process.

\section{Conclusion}

This paper analysed the limits and possibilities of participatory democracy at the local level, using a municipal housing council as a case study. To that end, I used literature on participatory democracy in order to shed light on the process of citizen participation and integration in spaces of decision-making. Despite some government efforts towards a largely open and inclusive space for creating bottom-up active participation, central obstacles to the development of a fully-functioning participatory democracy remain in place in the municipality. Unequal power structures at local councils, the concentration of decision power the private construction sector has on social housing policymaking, 
barriers to citizen participation, and the lack of transparency when it comes to government decisions prevent civil society and social movements from having a more influential voice in decision-making in those spaces.

The findings presented in this paper are important for two reasons. Firstly, they propose that the Brazilian state has made some minimal adjustments to its procedures to include SMOs in the process of decision-making, but at the same time there are imposed limitations on the full citizen participation. Secondly, these limitations come from a participatory model in which the relevant decisions 'have been made elsewhere by someone else' (Fung, 2015, p. 513), in which outcomes may not be meaningful to participants, as a consequence of a poorly designed public engagement process.

The lack of inclusion and continuing unequal power structures is caused by structural inequality. On the one hand, elites control the decision-making arena and agenda and obtain most of the benefits. On the other hand, limited access to participation affects the ability of SMOs to influence the outcomes of social housing policies and this unequal division of power discourages active participation from SMO representatives. This model can limit the transformation potential of SMOs when it comes to more access to better housing. The integration of social movements in local government does not fully replace the traditional representative political model. In practice, this new participatory model frequently interacts with the old, in the form of a clash with 'old politics'. More recently, as a result, of political changes in Brazil, the structures democratic innovations are in jeopardy.

The 2016 parliamentary coup reinstated an elitist, majoritarian white, right-wing government, expressing the dissatisfaction of Brazilian elites in accepting the expansion citizenship rights, putting an end to a cycle of democratization that commenced nearly 30 years ago (Lima, in press). The political crisis that has affected Brazil since 2016, caused by a deep economic crisis and weak government without legitimacy and leadership, creates opportunities for democratic innovations that seek to build legitimacy for the legal and administrative changes needed, and an opportunity to reflect on institutional design problems. As one of the values that drive participatory innovation, the legitimacy that would come from forms of direct citizen participation into the policymaking process would consist of political solutions backed up by the general public where possible. Going in the opposite direction, recent conservative measures have emerged, arguing that previous arrangements to promote citizen participation were too costly and lacked transparency, leading to the closing of several policy councils both at the local and national level. This has fostered a debate over the dismantling of citizen participation bodies in Brazil.

This imperfect model of participatory governance highlights the conflicting relationship of cooperation and contestation for those trying to influence the policy process. Considering that participatory governance is a crucial instrument for enabling popular participation and the representation of the interests of the poor, a full citizenship experience is the ultimate goal and the most difficult challenge for both civil society and governments. It remains to be seen whether elites can take part in spaces of participation and whether they can find a common agenda with representatives of the popular sector, or if this an intrinsic limitation of participatory democracy. 


\section{Notes}

1. In this sense, there is no relation between the creation of the council in Maracanau and the political party in power at the local level: the national legislation in place influenced the creation of the council. The council was created and fully operational in 2007.

2. Information from meeting minutes. Out of 16 meeting minutes, seven of them consisted of public officials informing the plenary of their plans for housing projects. For example, in the minutes of a meeting on 05.07.2011 (page 1, line 14-18) representatives of the infrastructure secretariat showed a set of slides on government plans for a housing project renovation on the southeast side of the municipality. There was no discussion or debate about the proposal. The meeting then moved on to another topic. In another meeting (16.10.12, page $1,24-29)$ when the plenary started to make questions about the project being presented, the person writing the meeting minutes stated that most of the questions coming from the plenary were not related to the topic under discussion.

3. Personal interview conducted in August 2014.

4. Personal Interview conducted in August 2014.

5. Minutes of a meeting on 14.11.2012, and on 11.02.2013.

6. Names were changed to preserve anonymity.

7. Interview conducted in September 2014.

\section{Disclosure statement}

No potential conflict of interest was reported by the author.

\section{Funding}

This work was supported by the Irish Research Council [GOIPG2014/236].

\section{Notes on contributor}

Valesca Lima is Dr Valesca Lima is a postdoctoral research fellow at Maynooth University. Her research topics include local government, citizenship and comparative housing policies.

\section{References}

Abers, R. (2000). Inventing local democracy: Grassroots politics in Brazil. Colorado: Lynne Rienner Publishers.

Arnstein, S. R. (1969). A ladder of citizen participation. Journal of the American Institute of Planners, 35(4), 216-224.

Avritzer, L. (2009). Participatory institutions in democratic Brazil. Baltimore: The Johns Hopkins University Press.

Baiocchi, G. (2003). Emergent public spheres: Talking politics in participatory governance. American Sociological Review, 68(1), 52-74.

Baiocchi, G., Braathen, E., \& Teixeira, A. C. (2013). Transformation institutionalized? Making sense of participatory democracy in the Lula Era. In G. Baiocchi, E. Braathen \& A. C. Teixeira (Eds.), Democratization in the global South (pp. 217-239). London: Palgrave Macmillan. https://link.springer.com/chapter/10.1057\%2F9780230370043_10

Baiocchi, G., \& Ganuza, E. (2016). Popular democracy: The paradox of participation (1 ed.). Stanford, California: Stanford University Press.

Baiocchi, G., Heller, P., \& Silva, M. (2011). Bootstrapping democracy: Transforming local governance and civil society in Brazil. California: Stanford University Press. 
Boito, A, \& Berringer, T. (2014). Social classes, neodevelopmentalism, and brazilian foreign policy under presidents lula and dilma. Latin American Perspectives, 41(5), 94-109.

Boito, A., \& Saad-Filho, A. (2016). State, state institutions, and political power in Brazil. Latin American Perspectives, 43(2), 190-206.

Bronstein, M. M., Filho, F., Rubens, J., \& Pimenta, G. A. (2017). Organização dos conselhos municipais: Governança e participação da sociedade civil [Municipal Councils Organization: Governance and Civil Society Participation]. Interações (Campo Grande), $18(1), 89-102$.

Cannon, B. (2016). The right in Latin America: Elite power, hegemony and the struggle for the state. Oxfordshire, UK: Routledge.

Carlos, E., Silva, R. D., \& Almeida, C. (2018). Participação e política pública: Efetividade dos conselhos de assistência social na gestão da política. Revista De Sociologia E Política, 26(67), 67-90.

Cohen, J. L. (1999). Changing paradigms of citizenship and the exclusiveness of the demos. International Sociology, 14(3), 245-268.

Cornwall, A. (2008). Unpacking 'participation': models, meanings and practices. Community Development Journal, 43(3), 269-283.

Dagnino, E. (2007). Citizenship: A perverse confluence. Development in Practice, 17(4-5), 549-556.

Dagnino, E., Olvera, A., \& Panfichi, A. (2006). A Disputa Pela Construção Democrática na América Latina [The Dispute for Democratic Construction in Latin America]. Sao Paulo: Paz e Terra.

Dagnino, E, \& Teixeira, A. C. C. (2014). The participation of civil society in lula's government. Journal Of Politics in Latin America, 6(3), 39-66.

Donaghy, M. M. (2011). Do participatory governance institutions matter?: Municipal councils and social housing programs in Brazil. Comparative Politics, 44(1), 83-102.

Donaghy, M. M. (2013). Civil society and participatory governance: municipal councils and social housing programs in brazil. Routledge.

Earle, L. O. (2009). Occupying the illegal city: Urban social movements and transgressive citizenship in Sao Paulo. (phd). London School of Economics and Political Science (United Kingdom).

Fishkin, J. S. (2009). When the people speak: Deliberative democracy and public consultation. (Reprint ed). Oxford: Oxford University Press.

Fishkin, J. S., \& Luskin, R. C. (2005). Experimenting with a democratic ideal: Deliberative polling and public opinion. Acta Politica, 40(3), 284-298.

Fung, A. (2015). Putting the public back into governance: the challenges of citizen participation and its future. Public Administration Review, 75(4), 513-522.

Fung, A., \& Wright, E. O. (2003). Deepening democracy: Institutional innovations in empowered participatory governance. Brooklyn, NY: Verso.

Garmany, J. (2011). Situating Fortaleza: Urban space and uneven development in Northeastern Brazil. Cities, 28(1), 45-52.

Gohn, M. D. G. (2015). Brazilian social movements in the last decade. In P. Almeida \& A. Cordero Ulate (Eds.), Handbook of social movements across Latin America (pp. 361-372). Dordrecht: Springer.

Goldfrank, B., \& Wampler, B. (2008). From Petista Way to Brazilian Way: How the PT Changes in the Road. Revista Debates, 2(2), 245-271.

Heller, P. (2012). Democracy, participatory politics and development: some comparative lessons from Brazil, India and South Africa. Polity, 44, 643- 665.

Hodgson, L. (2004). Manufactured civil society: Counting the cost. Critical Social Policy, 24(2), 139-164.

Kowarick, L. (2009). Viver em risco - Sobre a vulnerabilidade econômica e civil [Living at risk About economic and civil vulnerability]. Sao Paulo: Editora 34.

Lima, V. (2018). Social housing under the Workers' Party government: An analysis of the private sector in Brazil. Third World Quarterly, 39(8), 1640-1655. 
Lima, V. (in press). Participatory citizenship and crisis in contemporary Brazil (1st ed.). US: Palgrave Macmillan.

López-Calva, L. F., \& Lustig, N. C. (2010). Declining Inequality in Latin America: A decade of progress? Washington, DC: Brookings Institution Press.

Nylen, W. R. (2011). Participatory institutions in Latin America: The next generation of scholarship. Comparative Politics, 43(4), 479-497.

Polletta, F. (2013). Participatory democracy in the New Millennium. Contemporary Sociology, 42 (1), 40-50.

Rodgers, D., Beall, J., \& Kanbur, R. (2012). Re-thinking the Latin American City. In D. Rodgers, J. Beall, R. Kanbur (Eds.), Latin American urban development into the twenty first century (pp. 3-35). UK: Palgrave Macmillan.

Smith, G. (2009). Democratic Innovations. Cambridge: Cambridge University Press.

Souza, J. (2017). A elite do Atraso - Da Escravidão à Lava-Jato [The backwards elite - From slavery to the "Lava jato"operation] (1st ed.). Rio de Janeiro: Leya Brasil.

Tatagiba, L., \& Teixeira, A. C. C. (2016). Efeitos combinados dos movimentos de moradia sobre os programas habitacionais autogestionários [Combined effects of housing movements on selfmanaged housing programs]. Revista De Sociologia E Política, 24(58), 85-102.

Touchton, M., Wampler, B., \& Borges Sugiyama, N. (2016). Participation and the poor: Social accountability institutions and poverty reduction in Brazil. Southern Political Science Association, 1-50. San Juan, Puerto Rico.

Wampler, B. (2007). Participatory budgeting in Brazil: Contestation, cooperation, and accountability. University Park, PA: Penn State Press.

Wampler, B. (2008). When does participatory democracy deepen the quality of democracy? Lessons from Brazil. Comparative Politics, 41(1), 61-81.

Wampler, B., \& Touchton, M. (2014). Improving social well-being through new democratic institutions. Comparative Political Studies, 47(10), 1442-1469.

Wendhausen, Á., \& Caponi, S. (2002). Dialogue and participation in a local health council in the State of Santa Catarina, Brazil. Cadernos De Saúde Pública, 18(6), 1621-1628.

Yin, R. K. (2003). Case study research: Design and methods. London, UK: SAGE Publications. 